\title{
cDNA cloning of chicken orexin receptor and tissue distribution: sexually dimorphic expression in chicken gonads
}

\author{
T Ohkubo, A Tsukada ${ }^{1}$ and K Shamoto \\ Faculty of Agriculture, Kagawa University, Miki, Kagawa 761-0795, Japan \\ ${ }^{1}$ Department of Animal Physiology, Graduate School of Bioagricultural Sciences, Nagoya University, Nagoya, Aichi 464-8601, Japan \\ (Requests for offprints should be addressed to T Ohkubo; Email: ohkubo@ag.kagawa-u.ac.jp)
}

\begin{abstract}
Orexin-A and -B are known to stimulate food intake in mammals. However, the critical roles of orexins in birds are not fully understood, since orexins have no stimulatory effect on food intake in the chicken. To understand the physiological role(s) of orexins in birds, we have cloned chicken orexin receptor (cOXR) cDNA by RT-PCR, and analysed the tissue distribution of OXR mRNA in the chicken. The cOXR cDNA is 1869 bp long and encodes 501 amino acids. The cloned cDNA for cOXR corresponds to the type 2 OXR in mammals, and shows approximately $80 \%$ similarity to those of mammals at the amino acid level. Expression analysis by RNase protection assay revealed OXR mRNA was distributed widely in brain regions, and expression in the cerebrum, hypothalamus and optic tectum were abundant. In peripheral tissues, OXR mRNA was expressed in the pituitary gland, adrenal gland and testis, but no mRNA expression was observed in other tissues examined. Furthermore, we found that the amount of cOXR mRNA was different between testis and ovary, while prepro-orexin mRNA is equally expressed in the gonads of both sexes in the chicken. These data indicate that the orexins have neuroendocrine actions in chickens, which are mediated through hypothalamic receptors as has been observed in mammals. In addition, orexin may have specific role(s) in the regulation of gonadal function in which sex-dependent mechanisms could be involved.
\end{abstract}

Journal of Molecular Endocrinology (2003) 31, 499-508

\section{Introduction}

The neuropeptides orexin- $\mathrm{A}$ and $-\mathrm{B}$ have been identified as endogenous ligands for two orphan G-protein coupled receptors and were shown to stimulate food intake in rodents (Sakurai et al. 1998). The cellular localisation of the orexinproducing cells was restricted in the hypothalamus, but neurons expressing orexins project widely throughout the brain (Peyron et al. 1998, Date et al. 1999). Orexins bind and activate two subtypes of receptor called type 1 OXR (OX1R) and type 2 OXR (OX2R) (Sakurai et al. 1998), and these are widely distributed throughout the brain in the rat (Trivedi et al. 1998, Marcus et al. 2001). Consistent with this, physiological studies have implicated orexin peptides in the control of food and water intake, cardiovascular function, sleep-wake cycle
Table 1 Sequences of oligonucleotide primers for PCR

$\begin{array}{ll}\text { Orexin receptor } \\ \text { Primer } 1 & \text { AACCACCACATGAGGACAGTCACC } \\ \text { Primer } 2 & \text { CGCAGCACTATTGGCATATACAA } \\ \text { Primer } 3 & \text { GTGACAAATTGCATACCATCGATCC } \\ \text { Primer } 4 & \text { TGCTGGAAGACAAGTAATTGTGACC } \\ \text { Primer } 5 & \text { AATGGAAGTCTCTGCAGTCCTCAGC } \\ \text { Primer } 6 & \text { CACGTATGCTAATGGTTGTCCTCCT } \\ \text { Primer } 7 & \text { ACAGTTTCAGTCTCTGTGTC } \\ \text { Primer } 8 & \text { CCAGTGTTCATCACACACTG }\end{array}$

Prepro-orexin

Primer 1 ATGGAGGTGCCCAACGCCAAGCTGC

Primer 2 CAGGTCCTTCTCAGCGTGCTCCTGG

and neuroendocrine secretion in the central nervous system in mammals (Hagan et al. 1999, de Lecea \& Sutcliffe 1999, Sakurai 1999). In addition, peripheral localisation of OXRs was reported in 
GGCAATCACAAGTCTCAATGGAGGGGCGGGAGAGAGCTGTGGAGCGCTGAGAGGGTTCCTCCAGCCCCCCGGATCACCACCAGGGATGTC 90

CGGGACTCAGCCCGAGGATGTTTCGCCTCCGTGCAGGGACTGGACGTCCTCTCCAGAGCTGAACGAAACGCGGGAGCCCTTTTTAAACCC 180 $\begin{array}{lllllllllllllllllllllllllllllllllllll}G & T & Q & P & E & D & V & S & P & P & C & R & D & W & T & S & S & P & E & L & N & E & T & R & E & P & F & L & N & P & 32\end{array}$ ATCCGCCGATTACGACGATGAGGAGTTTCTGCGCTACCTCTGGAAgGAGTATTTGCATCCCAAGGGATACGAATGGGCGCTGATCGCCGG 270 $\begin{array}{llllllllllllllllllllllllllllllllllll}S & A & D & Y & D & D & E & E & F & L & R & Y & L & W & K & E & Y & L & H & P & K & G & Y & E & W & A & L & I & A & G & 62\end{array}$ AtACATCGTCGTGTTCATCGTGGCTCTCGTCGGGAACGTGCTGGTTTGTATTGCAGTGTGGAAGAACCATCACATGCGAACAGTCACCAA 360 $\begin{array}{llllllllllllllllllllllllllllllllll}\mathrm{Y} & \mathrm{I} & \mathrm{V} & \mathrm{V} & \mathrm{F} & \mathrm{I} & \mathrm{V} & \mathrm{A} & \mathrm{L} & \mathrm{V} & \mathrm{G} & \mathrm{N} & \mathrm{V} & \mathrm{L} & \mathrm{V} & \mathrm{C} & \mathrm{I} & \mathrm{A} & \mathrm{V} & \mathrm{W} & \mathrm{K} & \mathrm{N} & \mathrm{H} & \mathrm{H} & \mathrm{M} & \mathrm{R} & \mathrm{T} & \mathrm{V} & \mathrm{T} & \mathrm{N} & 92\end{array}$

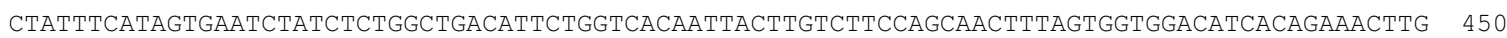

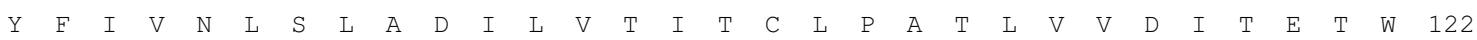
GTTCTTTGGGCACCACCTCTGCAAAGCAATTCCCTACTTACAGACAGTTTCAGTCTCTGTGTCTGTACTAACACTTAGCTGCATTGCTTT 540

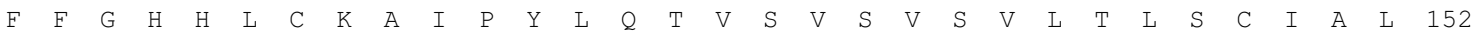
GGATCGATGGTATGCAATTTGTCACCCTTTGATGTTTAAAAGCACAGCCAAGCGTGCAAGGAACAGCATTATAATTATCTGGATTGTGTC 630 $\begin{array}{llllllllllllllllllllllllllllllllllllll}D & R & W & Y & A & I & C & H & P & \text { L } & M & F & K & S & T & A & K & R & A & R & N & S & I & I & I & I & W & I & V & S & 182\end{array}$ CTGCATCATAATGATTCCTCAGGCTATTGTTATGGAGTGCAGCAGCGTGTTCCCAGGATTAGCCAATAAAACCACCTTGTTCACAGTGTG 720 $\begin{array}{lllllllllllllllllllllllllllllllll}\mathrm{C} & \mathrm{I} & \mathrm{I} & \mathrm{M} & \mathrm{I} & \mathrm{P} & \mathrm{Q} & \mathrm{A} & \mathrm{I} & \mathrm{V} & \mathrm{M} & \mathrm{E} & \mathrm{C} & \mathrm{S} & \mathrm{S} & \mathrm{V} & \mathrm{F} & \mathrm{P} & \mathrm{G} & \mathrm{L} & \mathrm{A} & \mathrm{N} & \mathrm{K} & \mathrm{T} & \mathrm{T} & \mathrm{L} & \mathrm{F} & \mathrm{T} & \mathrm{V} & \mathrm{C} & 212\end{array}$ TGATGAACACTGGGGAGCTGAGGTTTACCCCAAAATGTATCATACATGCTTTTTCCTGGTGACGTACATGGCACCACTGTGTCTGATGGT 810 $\begin{array}{lllllllllllllllllllllllllllllll}\mathrm{D} & \mathrm{E} & \mathrm{H} & \mathrm{W} & \mathrm{G} & \mathrm{A} & \mathrm{E} & \mathrm{V} & \mathrm{Y} & \mathrm{P} & \mathrm{K} & \mathrm{M} & \mathrm{Y} & \mathrm{H} & \mathrm{T} & \mathrm{C} & \mathrm{F} & \mathrm{F} & \mathrm{L} & \mathrm{V} & \mathrm{T} & \mathrm{Y} & \mathrm{M} & \mathrm{A} & \mathrm{P} & \mathrm{L} & \mathrm{C} & \mathrm{L} & \mathrm{M} & \mathrm{V} & 242\end{array}$ GTTGGCCTATTTGCAAATATTTCGCAAGCTGTGGTGTCGCCAGATCCCTGGAACTTCTTCTGTCGTTCAGAAAAAATGGAAGTCTCTGCA 900 $\begin{array}{lllllllllllllllllllllllllllllllllllll}\mathrm{L} & \mathrm{A} & \mathrm{Y} & \mathrm{L} & \mathrm{Q} & \mathrm{I} & \mathrm{F} & \mathrm{R} & \mathrm{K} & \mathrm{L} & \mathrm{W} & \mathrm{C} & \mathrm{R} & \mathrm{Q} & \mathrm{I} & \mathrm{P} & \mathrm{G} & \mathrm{T} & \mathrm{S} & \mathrm{S} & \mathrm{V} & \mathrm{V} & \mathrm{Q} & \mathrm{K} & \mathrm{K} & \mathrm{W} & \mathrm{K} & \mathrm{S} & \mathrm{L} & \mathrm{Q} & 272\end{array}$ GTCCTCAGCACAGCAACGAGGGCTGGGACAGTCAACAAAGTCAAAGATCAGTGCTGTGGCAGCTGAAATAAAACAGATTCGTGCAAGAAG 990 $\begin{array}{llllllllllllllllllllllllllllllll}S & S & A & Q & Q & R & G & L & G & Q & S & T & K & S & K & I & S & A & V & A & A & E & I & K & Q & I & R & A & R & R & 302\end{array}$ GAAAACAGCACGTATGCTAATGGTTGTCCTCCTGGTTTTTGCACTTTGCTATCTGCCAATTAGCATCCTCAATATCTTGAAAAGGGTTTT 1080 $\begin{array}{llllllllllllllllllllllllllllllllll}\text { K } & \text { T } & \text { A } & R & \text { M } & \text { L } & \text { M } & \text { V } & \text { V } & \text { L } & \text { L } & \text { V } & \text { F } & \text { A } & \text { L } & \text { C } & \text { Y } & \text { L } & \text { P } & \text { I } & \text { S } & \text { I } & \text { L } & \text { N } & \text { I } & \text { L } & \text { K } & \text { R } & \text { V } & \text { F } & 332\end{array}$ TGGGATGTTTAATCATGCTGATGACAGAGAAACTGTATATGCCTGGTTCACATTCTCACACTGGCTTGTATATGCAAACAGTGCAGCCAA 1070 $\begin{array}{lllllllllllllllllllllllllllllllll}G & M & F & N & H & A & D & D & R & E & \text { T } & \text { V } & \text { Y } & \text { A } & \text { W } & \text { F } & \text { T } & \text { F } & \text { S } & \text { H } & \text { W } & \text { L } & \text { V } & \text { Y } & \text { A } & \text { N } & \text { S } & \text { A } & \text { A } & \text { N } & 362\end{array}$ TCCTATTATTTATAACTTCCTCAGTGGGAAGTTTAGAGAAGAATTAAAGCAGCGTTTTCTTGTTGCATCTTTGGTATTCACAGTCACCA 1260 $\begin{array}{llllllllllllllllllllllllllllllllllllllllll}P & I & I & Y & N & F & L & S & G & K & F & R & E & E & F & K & A & A & F & S & C & C & I & F & G & I & H & S & H & H & 392\end{array}$ TGATGAACGGCTTACAAGAGGTCGTGCCAGTACAGAGAGTCGGAAATCTTTGACCACCCAGATCAGCAATTTTGACAATGTTTCAAAACA 1350 $\begin{array}{lllllllllllllllllllllllllllllllllllllll}D & E & R & L & T & R & G & R & A & S & T & E & S & R & K & S & L & T & T & Q & I & S & N & F & D & N & V & S & K & H & 422\end{array}$ TTCAGAACATGTCCTGCTGACCAACATAAACACACTTACGGCAAATGGTATTACAGCTACATTCAGCCCTTTGAAGTCAATGGAACTGCA 1440

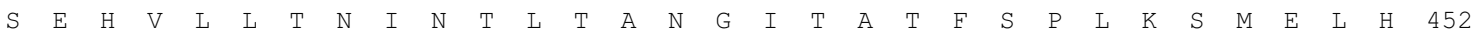
TCTCCACATACCAGGGGTGAACGTGTCTTCAAATTTAGATGAAGCAGTGAGAATTTCTGCAGGATGTACTGGCAACACAGAGAATGCAGA 1530 $\begin{array}{lllllllllllllllllllllllllllllllllll}\mathrm{L} & \mathrm{H} & \mathrm{I} & \mathrm{P} & \mathrm{G} & \mathrm{V} & \mathrm{N} & \mathrm{V} & \mathrm{S} & \mathrm{S} & \mathrm{N} & \mathrm{L} & \mathrm{D} & \mathrm{E} & \mathrm{A} & \mathrm{V} & \mathrm{R} & \mathrm{I} & \mathrm{S} & \mathrm{A} & \mathrm{G} & \mathrm{C} & \mathrm{T} & \mathrm{G} & \mathrm{N} & \mathrm{T} & \mathrm{E} & \mathrm{N} & \mathrm{A} & \mathrm{E} & 482\end{array}$ ATGGGATAAATTTGTCCCTAGTGTAACTAAACTTACCTCAATGGAATTACAGCAAGGATGACTTTGGCTCAAtACAgCTGAGAATGGCAT 1620

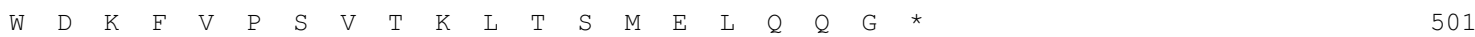
TTGTTTTAGCTGTGTTACAGACTAGAATAACTGGACAAAAGGATTCCTGCAAAACGACTGCCTCTTCTACCTCTTCTCAGTCTTATGGA 1710 AACCTACTTACCTCAGTATGAGCTAAACAACGTCTTTACAAGTCTTTTTAAAGAATGGATTGTATCATACTTTGTAAATACTGTAGATAT 1800 
mammals (Jöhren et al. 2001, Blanco et al. 2002, Näslund et al. 2002), and peripheral actions of orexins are also discussed (Kirchgessner 2002, Smart \& Jerman 2002).

On the other hand, information on the orexin pathway and its actions are very limited in non-mammalian vertebrates. In teleost fish, central injection of human orexin peptides can stimulate food intake in goldfish (Volkoff et al. 1999, Volkoff \& Peter 2001). Contrary to results demonstrated in other species, human orexins did not stimulate food intake in neonatal chicks (Furuse et al. 1999). In addition, we recently cloned prepro-orexin cDNA from chicken hypothalamus and described that food deprivation for $24 \mathrm{~h}$ did not alter orexin mRNA expression in the chicken hypothalamus (Ohkubo et al. 2002). In amphibians, the Xenopus orexin gene has been cloned and the peptides were bioactive in a human OXR in vitro functional assay; however, in vivo actions of orexin were not addressed (Shibahara et al. 1999). Furthermore, there is no available report describing cDNA cloning for $\mathrm{OXR}(\mathrm{s})$ in non-mammalian species, and the tissue distribution of the receptor would be invaluable for gaining insight into the physiological actions of orexin in non-mammalian vertebrates. At least in birds, data suggest that orexin is not involved in the regulation of food intake (Furuse et al. 1999, Ohkubo et al. 2002); thus alternative functions other than orexigenic actions should be clarified. To address this issue, we aimed to clone chicken OXR (cOXR) cDNA and reveal tissue distribution of the mRNA in both central and peripheral tissues in the chicken.

\section{Materials and methods}

\section{Animals}

White Leghorn chickens were purchased from a local hatchery and maintained under long-day conditions (14 h light/day) at an ambient temperature of $20-23{ }^{\circ} \mathrm{C}$ with free access to food and water. At 20 weeks of age, the chickens were killed by cervical dislocation and tissues were immediately removed and frozen in liquid nitrogen before RNA extraction. Animal procedures were performed according to the guidelines of the Experimental Animal Care Committee of Kagawa University.

\section{Primers}

The primers used in this study are listed in Table 1 . Primers 1 and 2 for OXR were designed from the conserved nucleotide sequence in mammalian OXRs (Sakurai et al. 1998, Lin et al. 1999). Other primers were synthesised as specific primers to cOXR cDNA or chicken prepro-orexin cDNA.

\section{cDNA cloning of cOXR by RT-PCR}

Total RNA was extracted from chicken hypothalamus using a commercial kit (ISOGEN; Nippon Gene, Toyama, Japan) and poly $(\mathrm{A})^{+}$RNA was isolated with Oligotex-dT30 (TaKaRa, Osaka, Japan). One microgram of poly (A) ${ }^{+}$RNA was used to prepare a cDNA library with a Marathon cDNA amplification kit (Clontech Laboratories, Palo Alto, CA, USA). A cDNA fragment for cOXR was amplified with primers 1 and 2 with TaKaRa Ex Taq (TaKaRa) by 30 cycles of PCR consisting of denaturation for $30 \mathrm{~s}$ at $95{ }^{\circ} \mathrm{C}$, annealing for $30 \mathrm{~s}$ at $58{ }^{\circ} \mathrm{C}$ and extension for $1 \mathrm{~min}$ at $72^{\circ} \mathrm{C}$. The $5^{\prime}$ and $3^{\prime}$-ends of the cOXR cDNA were amplified by rapid amplification of cDNA ends with the Marathon cDNA library according to the manufacturer's instruction with primers 3 (initial primer) and 4 (nested primer), and primers 5 (initial primer) and 6 (nested primer) respectively. All cDNA fragments were subcloned into pGEM-T easy vector (Promega, Madison, WI, USA) and both strands were sequenced with an Applied Biosystems 373A automated sequencer or ABI PRISM 310 automated sequencer (Applied Biosystems, Foster City, CA, USA).

\section{Southern blot analysis for cOXR}

Twenty micrograms chicken DNA were digested with BamHI, EcoRI and HindIII and electrophoresed on a $0 \cdot 6 \%$ agarose gel and blotted onto a nylon membrane. The genomic DNA fragments on the membrane were hybridised to a ${ }^{32} \mathrm{P}$-labelled

\footnotetext{
Figure 1 The nucleotide sequence of cOXR cDNA and the deduced amino acid sequence. Both strands were completely sequenced. The termination codon is marked with an asterisk. The nucleotide sequence data will appear in the EMBL/GenBank/DDBJ nucleotide databases with the accession number AB110634.
} 


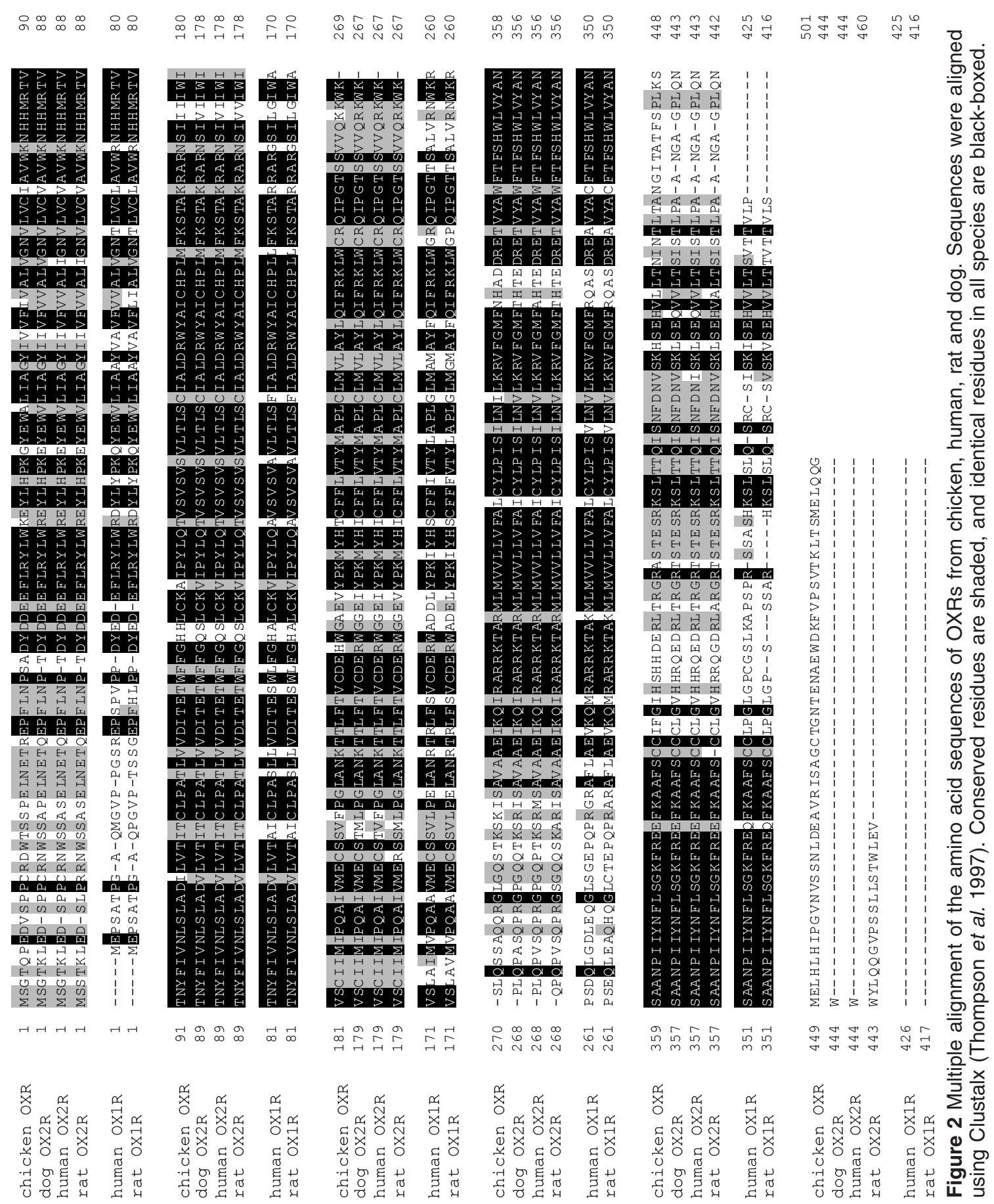




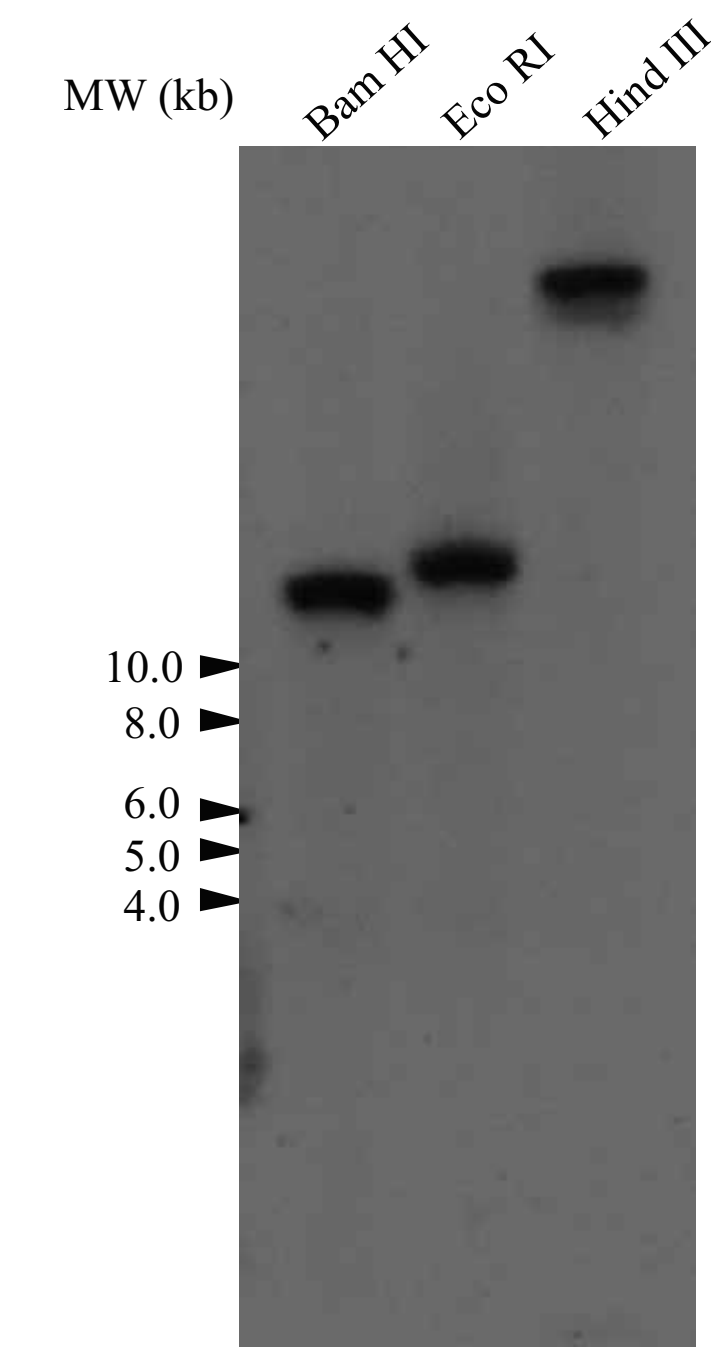

Figure 3 Southern blot analysis of the cOXR gene. DNA $(20 \mu \mathrm{g})$ isolated from chicken testis was digested with BamHI, EcoRI and HindIII and electrophoresed on a $0.6 \%$ agarose gel. The DNA was transferred to a nylon membrane and hybridised with a ${ }^{32} \mathrm{P}$-labelled cOXR cDNA probe, position from 494 to 565 .

cOXR cDNA probe, position from 494 to 565, that corresponds to the highly conserved sequence between OX1R and OX2R in mammals (Sakurai et al. 1998, Peyron et al. 2000) for $16 \mathrm{~h}$ at $37^{\circ} \mathrm{C}$ in a buffer consisting of $50 \%$ formamide, $5 \times$ Denhardt's solution $(1 \times$ Denhardt's solution; $0 \cdot 2 \%$ BSA, $0 \cdot 2 \%$ Ficoll 400 and $0 \cdot 2 \%$ polyvinylpyrrolidone $), 5 \times \mathrm{SSPE}(1 \times \mathrm{SSPE} ; 0.15 \mathrm{M} \mathrm{NaCl}$, $0.01 \mathrm{M} \mathrm{NaH}{ }_{2} \mathrm{PO}_{4}$ and $1 \mathrm{mM}$ EDTA), $0.2 \mathrm{mg} / \mathrm{ml}$ salmon sperm DNA and $0 \cdot 1 \%$ SDS. After low-stringency washing with $2 \times \mathrm{SSC}(1 \times \mathrm{SSC}$; $0.15 \mathrm{M} \mathrm{NaCl}$ and $0.015 \mathrm{M}$ sodium citrate) containing $0 \cdot 1 \%$ SDS for $30 \mathrm{~min}$ at $37^{\circ} \mathrm{C}$, hybridised genomic DNA fragments were visualised by autoradiography.

\section{RNase protection assay for cOXR mRNA}

For RNA probe preparation, cDNA fragments for cOXR, position from 330 to 565, and chicken S17 cDNA (Trüeb et al. 1988), position from 273 to 387 , were amplified by RT-PCR and cloned into pGEM-T easy vector. The antisense probes for cOXR and chicken S17 from the linealised plasmids were labelled with $\left[\alpha-{ }^{32} \mathrm{P}\right] \mathrm{CTP}$ (Amersham Bioscience, Piscataway, NJ, USA) using T7 RNA polymerase (Promega).

Total RNA $(20 \mu \mathrm{g})$ extracted from each chicken tissue was incubated with ${ }^{32} \mathrm{P}$-labelled cOXR and S17 complementary RNA probes for $16 \mathrm{~h}$ at $50{ }^{\circ} \mathrm{C}$ in $30 \mu \mathrm{l}$ hybridisation buffer containing 80\% formamide, $400 \mathrm{mM} \mathrm{NaCl}, 1 \mathrm{mM} \operatorname{EDTA}(\mathrm{pH} 8 \cdot 0$ ) and $40 \mathrm{mM}$ PIPES-NaOH $(\mathrm{pH} 6 \cdot 7$, piperazineN,N-bis-2-ethanesulphonic acid monosodium salt). Following digestion with RNases A $(40 \mu \mathrm{g} / \mathrm{ml})$ (Boehringer Mannheim) and T1 $(2 \mu \mathrm{g} / \mathrm{ml})$ (Boehringer Mannheim) for $30 \mathrm{~min}$ at $30^{\circ} \mathrm{C}$, the reaction mixture was treated with proteinase $\mathrm{K}$ (50 $\mu \mathrm{g} / \mathrm{ml}$ ) (Boehringer Mannheim, Tokyo, Japan) for $15 \mathrm{~min}$ at $37^{\circ} \mathrm{C}$. The samples were electrophoresed on a $6 \%$ polyacrylamide gel containing $7 \mathrm{M}$ urea to separate the protected RNA fragments. The specifically protected bands by cOXR and S17 RNA probes were determined by a Fuji BAS 2000 imaging analyser (Fuji Photo Film Co, Tokyo, Japan).

\section{Determination of prepro-orexin and OXR mRNAs in chicken gonads by RT-PCR}

The RT-PGR conditions for OXR expression in chicken gonads were the same as described above, except using primers 7 and 8. For prepro-orexin amplification by RT-PCR, a cDNA fragment for chicken orexin was amplified with primers 1 and 2, and FastStart Taq DNA polymerase (Roche Diagnostics, Penzberg, Germany). After sample denaturation and activation of the DNA polymerase at $95{ }^{\circ} \mathrm{C}$ for $4 \mathrm{~min}, 35$ cycles of PCR were carried out as follows: denaturation for $30 \mathrm{~s}$ at $95{ }^{\circ} \mathrm{C}$, annealing for $30 \mathrm{~s}$ at $65^{\circ} \mathrm{C}$ and extension for $1 \mathrm{~min}$ at $72{ }^{\circ} \mathrm{C}$. Amplification was terminated by a $7 \mathrm{~min}$ final extension step at $72^{\circ} \mathrm{C}$. Amplified 

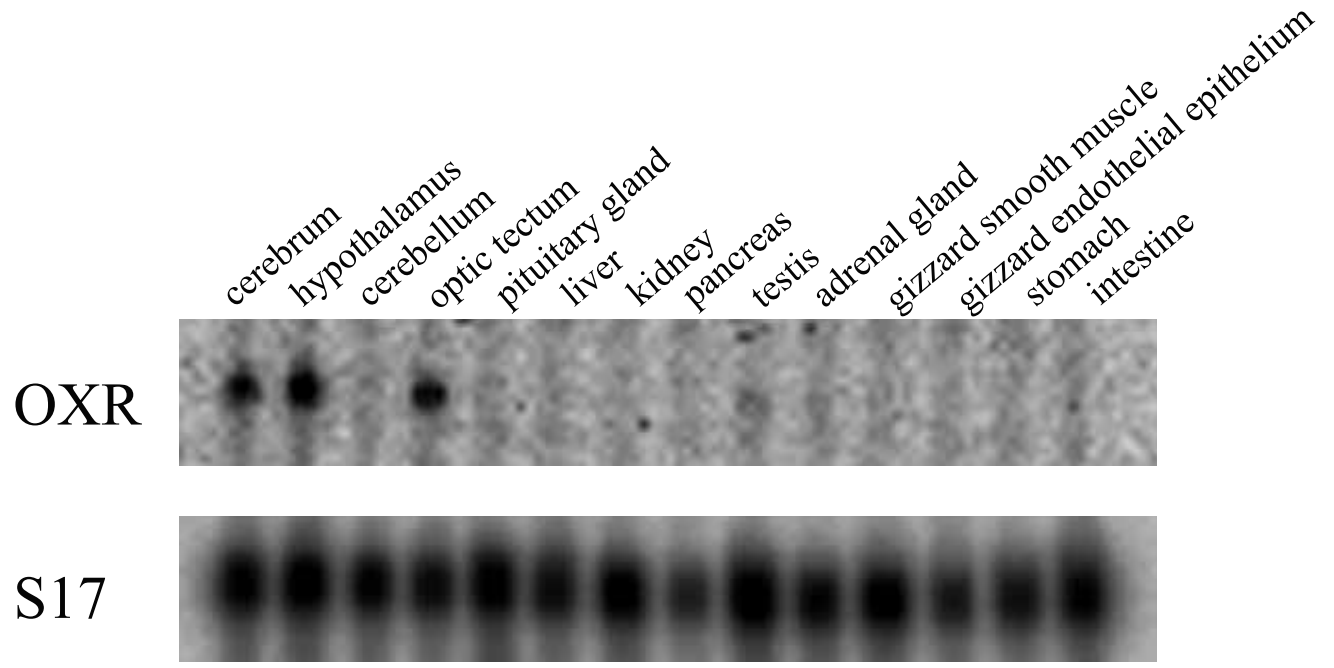

Figure 4 Tissue expression profiles of cOXR mRNA measured by RNase protection assay. Twenty micrograms total RNA from chicken tissues were subjected to hybridisation with antisense RNA probes for COXR and S17. The data represent an autoradiogram from three independent experiments.

cDNAs for chicken prepro-orexin and OXR were separated by electrophoresis on a $2 \%$ agarose gel and stained with ethidium bromide to visualise the amplified bands.

\section{Results}

\section{Structure of cOXR cDNA}

The nucleotide and deduced amino acid sequences of cOXR are shown in Fig. 1. The cOXR cDNA is $1869 \mathrm{bp}$ long and encodes 501 amino acids. Since cOXR showed approximately $80 \%$ similarity to OX2R, and approximately $70 \%$ identity with OX1R at the amino acid level (Fig. 2), the cOXR is predicted as a counterpart of $\mathrm{OX} 2 \mathrm{R}$ reported in mammals.

\section{Southern blot analysis of cOXR gene}

Using a low-stringency condition for Southern blot analysis, a single fragment was hybridised with the radiolabelled cOXR cDNA probe in all restriction enzyme treatments (Fig. 3).

\section{Determination of OXR mRNA expression in chicken tissues by RNase protection assay}

OXR mRNA was widely distributed in chicken brain, and abundant expression was observed in the cerebrum, hypothalamus and optic tectum. In peripheral tissues, mRNA for OXR was detected in the pituitary gland, adrenal gland and testis in the chicken (Fig. 4).

\section{Determination of prepro-orexin and OXR mRNAs in chicken gonads by RT-PCR}

OXR mRNA was detected in chicken gonads of both sexes, but the amount of OXR mRNA in the ovary is lower than that in testis (Fig. 5B). In addition, prepro-orexin mRNA was also expressed in chicken gonads, and the expression level was equivalent in the testis and ovary (Fig. 5A).

\section{Discussion}

This is the first report of the structure of the OXR in non-mammalian vertebrates. The cOXR showed high similarity with OX2R in mammals (Fig. 2), and phylogenetic analysis placed cOXR in the cluster of OX2R (Fig. 6). Thus, the cloned cOXR is likely to be the analogue of OX2R in mammals. However, low-stringency Southern blot analysis did not provide any evidence that a gene encoding OX1R exists in the chicken genome (Fig. 3). This result raises two possibilities: that there is no OX1R in the chicken or chicken $\mathrm{OX} 1 \mathrm{R}$ is sufficiently different from the cOXR and failed to 


\section{(A) Orexin}
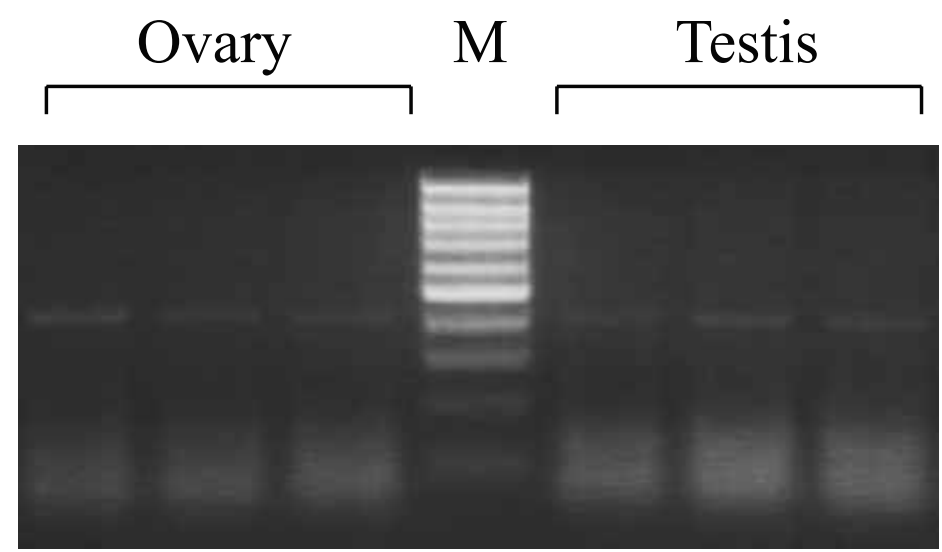

\section{(B) OXR}
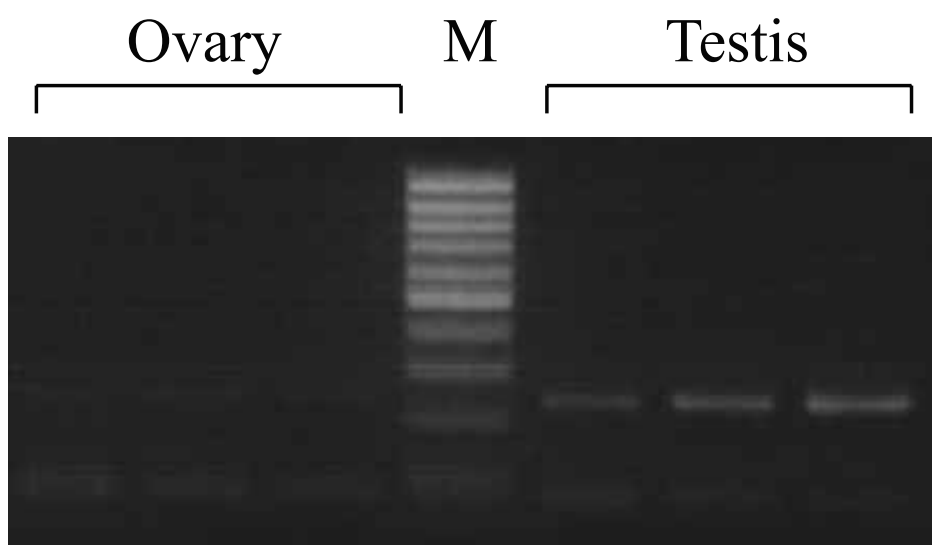

Figure 5 Semiquantitative analysis of chicken prepro-orexin $(A)$ and OXR (B) mRNAs in chicken gonads. Each fragment was amplified with appropriate PCR conditions and primers as described under Materials and methods. Amplified cDNAs for chicken orexin and OXR were separated by electrophoresis on a $2 \%$ agarose gel and stained with ethidium bromide to visualise the amplified bands. M, DNA size marker (100 bp DNA ladder, SIGMA Genosys, Tokyo, Japan).

cross-hybridise to the cOXR probe used for Southern analysis in this study. It is reported that OX2R binds orexin-A and -B with an equal affinity, while OX1R binds orexin-A with an affinity 10 times higher than for orexin-B (Sakurai et al. 1998). Furthermore, orexin-A is recognised as a more potent orexigenic peptide than orexin-B in mammals (Dube et al. 1999, Ida et al. 1999, Yamada et al. 2000). Although, strong evolutionary conservation of amino acid sequences of mature
orexin-A and -B are observed in different vertebrate classes including chicken (Sakurai et al. 1998, Dyer et al. 1999, Shibahara et al. 1999, Ohkubo et al. 2002), it is still difficult to explain why orexins do not stimulate food intake in birds. The absence of a functional OX1R may provide an explanation as to why orexins do not stimulate food intake in the chicken.

cOXR was distributed widely in chicken brain and abundant expression was observed in the 


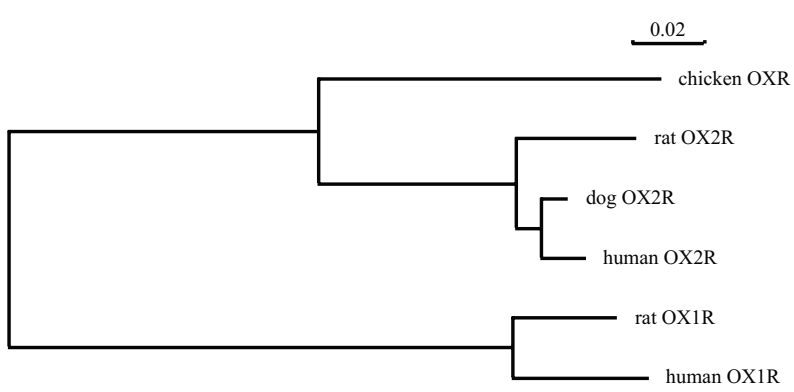

Figure 6 Phylogenetic analysis tree of vertebrate OXRs. The tree was constructed by the neighbour-joining method using a distance matrix based on amino acid sequences. Horizontal lines indicate genetic distance. The sequences were obtained from EMBL/GenBank Data Bank: human OX1R and OX2R (AF041243 and AF041245 respectively), rat OX1R and OX2R (AF041244 and AF041246 respectively) and dog OX2R (AF164626).

cerebrum, hypothalamus and optic tectum (Fig. 4). Localisation of OXRs in the central nervous system has been investigated with molecular-biological and immunological methods in the rat. OXRs are found at the projection sites of orexinergic neuron and in the many hypothalamic nuclei (Trivedi et al. 1998, Date et al. 2000, Marcus et al. 2001). In addition, our previous study showed that localisation of orexin-producing cells was restricted to the hypothalamus in the chicken (Ohkubo et al. 2002), in common with observations in mammals and amphibians (de Lecea \& Sutcliffe 1999, Sakurai 1999, Shibahara et al. 1999, Galas et al. 2001). Consequently, orexins exert multiple functions via hypothalamic and other brain receptors in the chicken. It is noteworthy that the optic tectum expresses high levels of OXR in the chicken. In the chicken, it has been reported that light stimulation modulates the $\gamma$-aminobutyric acid (GABA) system (Nistico et al. 1979) and experimental lighting circumstances affect the postnatal development of GABA receptor sites in the optic tectum (Rios et al. 1987). In the rat, orexins are suggested to excite GABAergic neurons via OX2R and that leads to maintenance of the arousal state (Martin et al. 2002, $\mathrm{Wu}$ et al. 2002, Korotkova et al. 2003). Taken together, chicken orexins may be involved in the visual processing mechanism, which might relate to the control of the sleep-wake cycle in the chicken.

Contrary to the situation in the brain, OXR expression in peripheral tissues was selective. Three out of nine tissues examined expressed OXR
(Fig. 4). It has been shown that i.c.v.-injected orexins increase plasma adrenocorticotrophin and corticosterone levels and reduce plasma prolactin and growth hormone levels (Hagan et al. 1999, Ida et al. 2000, Kuru et al. 2000). Also there is evidence that OX2R produced in the human adrenal cortex increases cAMP and inositol trisphosphate in vitro (Randeva et al. 2001). Consequently, the occurrence of OXRs in the pituitary and adrenal glands may suggest that the orexins, at least in part, play roles in these organs that are similar to those observed in mammals. However, whereas cOXR is likely to be a counterpart of OX2R in mammals (Figs 2 and 6), the expression profile of cOXR was slightly different from that of rat OX2R. For example, high levels of $\mathrm{OX} 2 \mathrm{R}$ are expressed in rat adrenal glands, whereas cOXR expression was very faint and is similar to levels of rat OX1R in the adrenal glands (Jöhren et al. 2001). In the testis, OXR was abundantly expressed in the chicken, whereas in the rat testis only OX1R was expressed (Jöhren et al. 2001). This may indicate that the orexin-OXR pathway in the chicken is different from that of the rat or other mammals. Moreover, we have carried out semiquantitative RT-PCR analysis for orexin and OXR in the gonads of both sexes (Fig. 5). Interestingly, we have found much higher levels of OXR mRNA in the testis when compared with that in the ovary (Fig. 5A). This result suggests that sex steroid hormones may differentially regulate gonadal OXR expression in the chicken. This view is supported by the observation that the sexually dimorphic expression of OXRs observed in rat pituitary and adrenal glands was critically regulated by gonadal steroids (Jöhren et al. 2003). For instance, the mRNA levels for OX1R in the pituitary gland and OX2R in the adrenal gland were higher in male rats compared with female rats. These receptors were downregulated by oestrogen in the female rat, while testosterone down- and up-regulates pituitary OX1R and adrenal OX2R expression in male rats respectively (Jöhren et al. 2003). Although we described a gender difference in OXR expression in chicken gonads and prepro-orexin mRNA is expressed in the testis and ovary, a prominent role of orexin in testicular or ovarian function is not clarified in any species. Consistent with our observation in this study, orexin mRNA is found in rat testis (Sakurai et al. 1998, Jöhren et al. 2001), and furthermore, at least in the rat, the mRNA is 
translated (Mitsuma et al. 2000a,b). It is notable that OXR and prepro-orexin are expressed in the ovary as well as in the testis of the chicken (Fig. 5). However, there are no reports of the functional relationship between orexin and the ovary in mammals. Ovarian OXRs have not been confirmed in any mammal, and no prepro-orexin mRNA was expressed in rat (Jöhren et al. 2001). In relation to orexin and gonadal actions, it is reported that orexins modulate luteinising hormone (LH) release from rat pituitary gland in an ovarian steroid-dependent manner ( $\mathrm{Pu}$ et al. 1998). Orexin A suppresses LH-releasing hormone (LHRH)stimulated LH release in dispersed anterior pituitaries from males and proestrous females, and hypothalamic responsiveness to orexin $\mathrm{A}$ on LHRH release is different in the stages of the oestrous cycle (Russell et al. 2001). These results strongly indicate that the steroid hormone state is responsible for orexin actions on the hypothalamopituitary gonadal axis. Therefore, it would be possible that orexin directly regulates gonadal functions. In the present study, we found expression of prepro-orexin and OXR mRNAs in the gonads of both sexes in chickens, which may suggest that orexins are involved in the control of gonadal function by a paracrine or endocrine manner in the chicken. Therefore, further studies of the functional relevance of gonadal orexin(s) are required. In addition, evidence as to whether or not other subtypes of OXR exist, and the localisation of $\operatorname{OXR}(s)$ in the central and peripheral tissues, will help us to understand neuroendocrine and endocrine actions of orexins in the chicken.

\section{Acknowledgements}

We thank Dr D Zadworny, McGill University, Canada, for reviewing the manuscript. This work was supported in part by a Grant-in-Aid for Encouragement of Young Scientists from the Japanese Ministry of Education, Science, Sports and Culture.

\section{References}

Blanco M, Garcia-Caballero T, Fraga M, Gallego R, Cuevas J, Forteza J, Beiras A \& Dieguez C 2002 Cellular localization of orexin receptors in human adrenal gland, adrenocortical adenomas and pheochromocytomas. Regulatory Peptides 104 $161-165$.
Date Y, Ueta Y, Yamashita H, Yamaguchi H, Matsukura S, Kangawa K, Sakurai T, Yanagisawa M \& Nakazato M 1999 Orexins, orexigenic hypothalamic peptides, interact with autonomic, neuroendocrine and neuroregulatory systems. PNAS $96748-753$.

Date Y, Mondal MS, Matsukura S, Ueta Y, Yamashita H, Kaiya H, Kangawa K \& Nakazato M 2000 Distribution of orexin/hypocretin in the rat median eminence and pituitary. Brain Research. Molecular Brain Research 76 1-6.

Dube MG, Kalra SP \& Kalra PS 1999 Food intake elicited by central administration of orexins/hypocretins: identification of hypothalamic sites of action. Brain Research 842 473-477.

Dyer CJ, Touchette KJ, Carroll JA, Allee GL \& Matteri RL 1999 Cloning of porcine prepro-orexin cDNA and effects of an intramuscular injection of synthetic porcine orexin-B on feed intake in young pigs. Domestic Animal Endocrinology 16 145-148.

Furuse M, Ando R, Bungo T, Ao R, Shimojo M \& Masuda Y 1999 Intracerebroventricular injection of orexins does not stimulate food intake in neonatal chicks. British Poultry Science 40 698-700.

Galas L, Vaudry H, Braun B, Van Den Pol AN, De Lecea L, Sutcliffe JG \& Chartrel N 2001 Immunohistochemical localization and biochemical characterization of hypocretin/orexin-related peptides in the central nervous system of the frog Rana ridibunda. Fournal of Comparative Neurology 429 242-252.

Hagan JJ, Leslie RA, Patel S, Evans ML, Wattam TA, Holmes S, Benham CD, Taylor SG, Routledge C, Hemmati P, Munton RP, Ashmeade TE, Shah AS, Hatcher JP, Hatcher PD, Jones DN, Smith MI, Piper DC, Hunter AJ, Porter RA \& Upton N 1999 Orexin A activates locus coeruleus cell firing and increases arousal in the rat. PNAS 96 10911-10916.

Ida T, Nakahara K, Katayama T, Murakami N \& Nakazato M 1999 Effect of lateral cerebroventricular injection of the appetitestimulating neuropeptides, orexin and neuropeptide $\mathrm{Y}$, on the various behavioral activities of rats. Brain Research 821 526-529.

Ida T, Nakahara K, Murakami T, Hanada R, Nakazato M \& Murakami N 2000 Possible involvement of orexin in the stress reaction in rats. Biochemical and Biophysical Research Communications $270318-323$.

Jöhren O, Neidert SJ, Kummer M, Dendorfer A \& Dominiak P 2001 Prepro-orexin and orexin receptor mRNAs are differentially expressed in peripheral tissues of male and female rats. Endocrinology 142 3324-3331.

Jöhren O, Bruggemann N, Dendorfer A \& Dominiak P 2003 Gonadal steroids differentially regulate the messenger ribonucleic acid expression of pituitary orexin type 1 receptors and adrenal orexin type 2 receptors. Endocrinology 144 1219-1225.

Kirchgessner AL 2002 Orexins in the brain-gut axis. Endocrine Revieres 23 1-15.

Korotkova TM, Sergeeva OA, Eriksson KS, Haas HL \& Brown RE 2003 Excitation of ventral tegmental area dopaminergic and nondopaminergic neurons by orexins/hypocretins. Fournal of Neuroscience 23 7-11.

Kuru M, Ueta Y, Serino R, Nakazato M, Yamamoto Y, Shibuya I \& Yamashita H 2000 Centrally administered orexin/hypocretin activates HPA axis in rats. Neuroreport 11 1977-1980.

de Lecea L \& Sutcliffe JG 1999 The hypocretins/orexins: novel hypothalamic neuropeptides involved in different physiological systems. Cellular and Molecular Life Sciences 56 473-480.

Lin L, Faraco J, Li R, Kadotani H, Rogers W, Lin X, Qiu X, de Jong PJ, Nishino S \& Mignot E 1999 The sleep disorder canine narcolepsy is caused by a mutation in the hypocretin (orexin) receptor 2 gene. Cell 98 365-376.

Marcus JN, Aschkenasi CJ, Lee CE, Chemelli RM, Saper CB, Yanagisawa M \& Elmquist JK 2001 Differential expression of orexin receptors 1 and 2 in the rat brain. Fournal of Comparative Neurology 435 6-25. 
Martin G, Fabre V, Siggins GR \& de Lecea L 2002 Interaction of the hypocretins with neurotransmitters in the nucleus accumbens. Regulatory Peptides 104 111-117.

Mitsuma T, Hirooka Y, Kayma M, Mori Y, Yokoi Y, Izumi M, Rhue N, Ping J, Adachi K, Ikai R, Kawai N, Nakayashiki A \& Nogimori T 2000a Radioimmunoassay for hypocretin-2. Endocrine Regulation 34 23-27.

Mitsuma T, Hirooka Y, Kayama M, Mori Y, Yokoi Y, Rhue N, Ping J, Izumi M, Ikai R, Adachi K \& Nogimori T $2000 b$ Radioimmunoassay for orexin A. Life Sciences 66 897-904.

Näslund E, Ehrstrom M, Ma J, Hellstrom PM \& Kirchgessner AL 2002 Localization and effects of orexin on fasting motility in the rat duodenum. American Fournal of Physiology. Gastrointestinal and Liver Physiology 282 G470-G479.

Nistico G, Ientile R, Rotiroti D \& Di Giorgio RM 1979 Lightevoked changes in chick optic lobe GABA system. Research Communications in Chemical and Pathological Pharmacology 24 447-456.

Ohkubo T, Boswell T \& Lumineau S 2002 Molecular cloning of chicken prepro-orexin cDNA and preferential expression in the chicken hypothalamus. Biochimica et Biophysica Acta 1577 476-480.

Peyron C, Tighe DK, van den Pol AN, de Lecea L, Heller HC, Sutcliffe JG \& Kilduff TS 1998 Neurons containing hypocretin (orexin) project to multiple neuronal systems. Fournal of Neuroscience $189996-10015$.

Peyron C, Faraco J, Rogers W, Ripley B, Overeem S, Charnay Y, Nevsimalova S, Aldrich M, Reynolds D, Albin R, Li R, Hungs M, Pedrazzoli M, Padigaru M, Kucherlapati M, Fan J, Maki R, Lammers GJ, Bouras C, Kucherlapati R, Nishino S \& Mignot E 2000 A mutation in a case of early onset narcolepsy and a generalized absence of hypocretin peptides in human narcoleptic brains. Nature Medicine 6 991-997.

Pu S, Jain MR, Kalra PS \& Kalra SP 1998 Orexins, a novel family of hypothalamic neuropeptides, modulate pituitary luteinizing hormone secretion in an ovarian steroid-dependent manner. Regulatory Peptides 78 133-136.

Randeva HS, Karteris E, Grammatopoulos D \& Hillhouse EW 2001 Expression of orexin-A and functional orexin type 2 receptors in the human adult adrenals: implications for adrenal function and energy homeostasis. Foumal of Clinical Endocrinology and Metabolism 86 4808-4813.

Rios H, Flores V \& Fiszer de Plazas S 1987 Effects of light- and dark-rearing on the postnatal development of GABA receptor sites in the chick optic lobe. International Fournal of Developmental Neuroscience 5 319-325.

Russell SH, Small CJ, Kennedy AR, Stanley SA, Seth A, Murphy KG, Taheri S, Ghati MA \& Bloom SR 2001 Orexin A interactions in the hypothalamo-pituitary gonadal axis. Endocrinology 142 5294-5302.

Sakurai T 1999 Orexins and orexin receptors: implication in feeding behavior. Regulatory Peptides 85 25-30.

Sakurai T, Amemiya A, Ishii M, Matsuzaki I, Chemelli RM, Tanaka H, Williams SC, Richardson JA, Kozlowski GP, Wilson S, Arch JR, Buckingham RE, Haynes AC, Carr SA, Annan RS, McNulty DE, Liu WS, Terrett JA, Elshourbagy NA, Bergsma DJ \& Yanagisawa M 1998 Orexins and orexin receptors: a family of hypothalamic neuropeptides and $\mathrm{G}$ protein-coupled receptors that regulate feeding behavior. Cell 92 573-585.

Shibahara M, Sakurai T, Nambu T, Takenouchi T, Iwaasa H, Egashira SI, Ihara M \& Goto K 1999 Structure, tissue distribution, and pharmacological characterization of Xenopus orexins. Peptides $201169-1176$.

Smart D \& Jerman J 2002 The physiology and pharmacology of the orexins. Pharmacology and Therapeutics 94 51-61.

Thompson JD, Gibson TJ, Plewniak F, Jeanmougin F \& Higgins D 1997 The CLUSTAL-X windows interface: flexible strategies for multiple sequence alignment aided by quality analysis tools. Nucleic Acid Research 25 4876-4882.

Trivedi P, Yu H, MacNeil DJ, Van der Ploeg LH \& Guan XM 1998 Distribution of orexin receptor mRNA in the rat brain. FEBS Letters 438 71-75.

Trüeb B, Schreier T, Winterhalter KH \& Strehler EE 1988 Sequence of a cDNA clone encoding chicken ribosomal protein S17. Nucleic Acids Research 164723.

Volkoff H \& Peter RE 2001 Interactions between orexin A, NPY and galanin in the control of food intake of the goldfish, Carassius auratus. Regulatory Peptides 101 59-72.

Volkoff H, Bjorklund JM \& Peter RE 1999 Stimulation of feeding behavior and food consumption in the goldfish, Carassius auratus, by orexin-A and orexin-B. Brain Research 846 204-209.

Wu M, Zhang Z, Leranth C, Xu C, van den Pol AN \& Alreja M 2002 Hypocretin increases impulse flow in the septohippocampal GABAergic pathway: implications for arousal via a mechanism of hippocampal disinhibition. Fournal of Neuroscience 22 7754-7765.

Yamada H, Okumura T, Motomura W, Kobayashi Y \& Kohgo Y 2000 Inhibition of food intake by central injection of anti-orexin antibody in rats. Biochemical and Biophysical Research Communications $267527-531$.

Received in final form 22 August 2003 Accepted 5 September 2003 